\title{
IN SUPPORT OF TOLERATED USE: RETHINKING HARMS, MORAL RIGHTS AND REMEDIES IN AUSTRALIAN COPYRIGHT LAW
}

\author{
KYLIE PAPPALARDO* AND JAMES MEESE ${ }^{* *}$
}

\begin{abstract}
In this article, we propose a thought experiment: what if copyright law could better incorporate social and cultural norms around content engagement and re-use? We draw on empirical research that explores the norms of different creative communities when they reuse the work of others, and the norms of consumers around sharing. We outline how both creators and copyright users engage almost daily in small-scale infringement that does not substitute or disrupt copyright owners' established markets, either because the uses are highly transformative, or personal and unremarkable. We suggest that copyright could better reflect these norms if both norms and moral rights were considered as part of a remedies assessment. We propose that in cases where work has been attributed and treated with integrity, and where the use does not directly cause economic harm to the copyright owner, courts should award only nominal damages and decline to order injunctive relief.
\end{abstract}

\section{INTRODUCTION}

It is uncontroversial to note that copyright law is not ideally suited to a digital environment. ${ }^{1}$ Despite the decrease in online copyright infringement over the past decade following the introduction of streaming media, ${ }^{2}$ there is still a foundational tension that resides around the enforcement of copyright online. Copyright, a legal framework that aims to establish a system of authorisation and control around the distribution of copies, has to work in concert with what Cory Doctorow has termed

\footnotetext{
* Lecturer, School of Law, Queensland University of Technology. Thanks to Nicolas Suzor for comments on earlier iterations of this article.

** Senior Lecturer, School of Communication, University of Technology Sydney. Thanks to Nick Jarvis for research assistance. This research was partially funded by a UTS Early Career Research Grant.

1 See, eg, Jessica Litman, Digital Copyright (Prometheus Books, $2^{\text {nd }}$ ed, 2006); Lawrence Lessig, Free Culture: How Big Media Uses Technology and the Law to Lock Down Culture and Control Creativity (Penguin Press, 2004).

2 James Meese, 'The Domestic Ecology of Australian Subscription Video on Demand Services' (2017) 164(1) Media International Australia 21, 24. See Ramon Lobato and James Meese, 'Geoblocking and Global Video Culture' (Reader No 18, Institute of Network Cultures, 2016).
} 
'the world's most efficient copying machine': the Internet. ${ }^{3}$ In addition to social changes brought about by the technical affordances of the Internet, there has been a dramatic change in the consumption practices of online audiences, who prefer to not just consume media but also to share it with friends, family members and colleagues, sometimes with and sometimes without the approval of the original copyright holder. ${ }^{4}$ As Tim Wu noted a decade ago, 'casual copyright infringement is sometimes a near-unavoidable part of many people's days'. ${ }^{5}$ This point was driven home in John Tehranian's 2011 book, Infringement Nation, which eloquently demonstrated just how routine and largely unremarkable ordinary acts of copyright infringement are in the day-to-day lives of most people. ${ }^{6}$

Both creators and copyright users alike engage almost daily in small-scale infringement that does not substitute or clearly disrupt copyright owners' established markets, either because the uses are highly transformative (such as using a small sample of an existing song in creating a new musical work) or personal and unremarkable (such as reposting a copyrighted image on an individual social media profile). These uses tend to fall into the space that Tim $\mathrm{Wu}$ has termed 'tolerated use' - a grey zone in copyright enforcement, comprising of uses that are technically infringing but mostly tolerated by copyright owners, usually because enforcement is not worth the effort. ${ }^{7}$ Ordinary creative practice, and digital and social media uses of content, tend to involve a high degree of tolerated use.

In this article, we propose a thought experiment: what if copyright law could better incorporate social and cultural norms around content engagement and reuse? Generally speaking, the law treats copyright infringement under a property rule, ${ }^{8}$ presuming that any infringement causes irreparable harm that justifies granting injunctive relief. ${ }^{9}$ But this presumption is not necessarily true. Where copying substitutes for a paid licence, it is often easier to say that the rights-holder suffers a loss in revenue. ${ }^{10}$ In many cases, however, copying does not result in any identifiable loss of revenue, and direct harm may often be presumed where it does not exist. ${ }^{11}$ We propose, instead, that non-substitutive uses should be treated under a liability rule. In cases where work has been attributed and treated with integrity, and where the use does not directly cause economic harm to the copyright owner,

Ben Murray, 'Remixing Culture and Why the Art of the Mash-Up Matters', TechCrunch (Online Article, 22 March 2015) <https://techcrunch.com/2015/03/22/from-artistic-to-technological-mash-up/>.

4 Corinne Tan, Regulating Content on Social Media: Copyright, Terms of Service and Technological Features (University College London Press, 2018) 5-6.

5 Tim Wu, 'Tolerated Use' (2008) 31(4) Columbia Journal of Law and the Arts 617, 618.

6 John Tehranian, Infringement Nation: Copyright 2.0 and You (Oxford University Press, 2011) ch 1.

7 Wu (n 5) 618.

8 See Guido Calabresi and A Douglas Melamed, 'Property Rules, Liability Rules, and Inalienability: One View of the Cathedral' (1972) 85(6) Harvard Law Review 1089.

9 See, eg, Copyright Act 1968 (Cth) s 115; Nationwide News Pty Ltd v Copyright Agency Ltd (1996) 65 FCR 399, 420 (Sackville J).

10 See, eg, Eagle Rock Entertainment Ltd v Caisley (2005) 66 IPR 554, 556-7 [11] (Tamberlin J); Australasian Performing Right Association Ltd v Cougars Tavern Pty Ltd [2008] FMCA 369, [18] (Raphael FM); Microsoft Corporation v Ezy Loans Pty Ltd (2004) 63 IPR 54, 76-7 [88]-[92] (Stone J).

11 See Nicolas Suzor, 'Access, Progress and Fairness: Rethinking Exclusivity in Copyright' (2013) 15(2) Vanderbilt Journal of Entertainment and Technology Law 297. See especially at 339. 
we suggest that courts should award only nominal damages and decline to order injunctive relief. This, we argue, would better align with cultural practice and the expectations of many creators and copyright users. ${ }^{12}$

In making these claims, we draw on empirical research that explores the norms of different creative communities when they re-use the work of others, and the norms of consumers around sharing. Our qualitative data emerges from individual interviews with a range of creators, and group interviews with consumers, conducted across Australia in 2016 and 2017. The interviews revealed that Australian creators and consumers regularly re-used copyrighted works without seeking permission from copyright owners. It became apparent from these interviews that while technical infringements were often taking place, both creators and consumers felt justified in their actions because they had treated the copyrighted work with respect and had attributed (or attempted to attribute) the original author. In short, their practices aligned closely with Australia's moral rights of integrity and attribution. Moreover, both consumers and creators presented a well-developed understanding of reasonableness as it relates to attribution, and creators also advanced a careful interpretation of what reasonableness looks like with reference to their understandings of authorial integrity. ${ }^{13}$

Our qualitative data leads us to suggest that copyright could be more closely aligned with norms around content engagement and re-use if both these norms and moral rights were considered as part of the assessment of remedies for infringement. This would not require any dramatic reworking of the legal tests for infringement, or any legislative reform. Rather, it would serve as legal recognition that not every unauthorised copy or use of a work harms a copyright owner. The assessment of remedies is a space that affords sufficient flex to a court to consider the totality of the circumstances relating to the infringing acts, including whether the use was substitutive or non-substitutive, and whether the original creator has been treated with respect under Australia's moral rights provisions. This is especially the case where remedies are discretionary, as they are for copyright infringement in Australia. ${ }^{14}$ Our argument proceeds on the basis that copyright is a legal framework that can and should aim to meaningfully regulate creative practice. Aligning the law with ordinary practices of creation, distribution and consumption will directly support the effectiveness and legitimacy of copyright

12 We should note that in this article, we do not consider cultural harm, particularly harm that can flow to Aboriginal and Torres Strait Islander persons from misappropriation of Indigenous artistic works: see, eg, Milpurrurru v Indofurn Pty Ltd (1994) 54 FCR 240; Bulun Bulun v R \& T Textiles Pty Ltd (1998) 86 FCR 244. We focus primarily on economic harm flowing from the reproduction and use of non-Indigenous works.

13 Our empirical research involved participants who were creators who engaged in some level of copyright re-use in their creative practice, and consumers on social media. We acknowledge that important stakeholders in copyright law are not represented in this study, especially many copyright owners, and that these stakeholders may not necessarily hold the view that certain infringements are harmless.

14 Cf statutory damages in the United States. See Andrew Trotter, 'Statutory Damages in Copyright' (2010) 21(4) Australian Intellectual Property Journal 219. 
law,,$^{15}$ as well as give greater relevance to underused moral rights provisions. Ultimately, we propose that ordinary uses and circulation of copyrighted works should not be restricted where there is no direct commercial harm to the copyright owner and where the works have been treated with respect in accordance with moral rights. ${ }^{16}$

This article is structured in seven parts. In Part II, we introduce the concept of copyright harm by discussing how remedies are determined for copyright infringement in Australia. We also consider Australia's moral rights regime and posit that a failure to attribute an author or treat a work with integrity should be considered as part of an understanding of 'copyright harm'. In Part III, we explain our methods for qualitative empirical research with Australian creators and copyright consumers. We present the findings from this research in Parts IV and V. Part IV covers copyright creators. We found that the creators we interviewed had a high tolerance for non-substitutive copyright infringement by other creators, provided that 'respect' was shown to them. Indeed, creators placed high importance on the giving and receiving of respect in re-use practices, which almost always required attribution as a minimum expectation. Part V discusses copyright consumers. We found that consumers also see attribution as an important ethical practice, though one with practical difficulties in the social media sharing environment. In Part VI, we draw together the findings from our creator and consumer studies to argue that copyright law can be better aligned to norms of creative practice through the assessment of remedies under law. We contend that norms of 'respectful re-use', which align closely with Australia's moral rights provisions, should matter in the determination of remedies for copyright infringement. Where re-use does not cause the copyright owner economic harm and is respectful, then the appropriate remedy may be nominal damages and no injunctive relief. We conclude in Part VII by suggesting that there are two key benefits arising from our proposal: first, aligning law with practice can help to support the perceived legitimacy of copyright law; and second, our approach might help to improve the balance between individual creators and users as against powerful corporate rights-holders, especially in cases of copyright litigation.

\section{UNPACKING COPYRIGHT HARM}

\section{A Copyright Remedies}

In Australia, copyright is governed by the Copyright Act 1968 (Cth) ('Copyright $A c t$ '), which extends protection to literary, artistic, musical and dramatic works in Part III and sound recordings and cinematograph films in Part

15 See Jessica Litman, 'Real Copyright Reform' (2010) 96(1) Iowa Law Review 1; Paula Dootson and Nicolas Suzor, 'The Game of Clones and the Australia Tax: Divergent Views about Copyright Business Models and the Willingness of Australian Consumers to Infringe' (2015) 38(1) University of New South Wales Law Journal 206.

16 As noted above, our arguments do not extend to cultural harms occasioned by unlicensed use and appropriation of creative works, particularly those experienced by Aboriginal and Torres Strait Islander creators. 
IV. ${ }^{17}$ Under the act, it is an infringement to reproduce a substantial part of a work or other subject matter without the permission of the copyright owner and without a legal exception. ${ }^{18}$ The exceptions to copyright infringement in Australia are limited, and will not generally apply to the kinds of creative or consumer uses that we discuss in this article. ${ }^{19}$

Copyright infringements are actionable per se, meaning that they are actionable upon a showing of infringement even in the absence of harm. ${ }^{20}$ Under section 115(2) of the Copyright Act, in an action for infringement, a court may grant an injunction and either damages or an account of profits. While an injunction is a discretionary remedy, the default position in copyright cases tends to be that the court will grant injunctive relief, because courts adopt the presumption that copyright infringement causes irreparable harm to the copyright owner. ${ }^{21}$ Evidence of actual economic harm, while not necessary for a successful action, may be relevant to an assessment of monetary damages.

The injunctive remedy available to courts in intellectual property cases has its origin in equity. An injunction is a discretionary remedy, ${ }^{22}$ and will not be awarded where damages are an adequate remedy. ${ }^{23}$ Cases have held that damages are inadequate where it is too difficult to calculate the damage likely to be suffered, ${ }^{24}$ or to prevent a 'multiplicity of actions' ${ }^{25}$ where the defendant threatens repeated or continuing infringements of a proprietary or possessory right. ${ }^{26}$ Injunctions have long been considered appropriate in intellectual property cases both because the economic harm occasioned by infringement - the kind of 'taking' where the owner

17 Copyright Act ss 10, 31, 32, 85-92.

18 Ibid ss 14, 36 (works), 101 (other subject matter).

19 The fair dealing exceptions appear in ibid ss 40-3, 103A-104, 113E, 113F. They apply to uses for the purposes of: research or study; criticism or review; reporting the news; parody or satire; judicial proceedings; and access for or by a person with a disability. In general, creative use for the purpose of creating a new work (eg remix or reappropriation) or consumer uses involving creating memes or sharing on social media will not fall within the ambit of any of the fair dealing exceptions. They also do not come within the many other exceptions contained in the Copyright Act that apply to use by libraries and cultural institutions (eg ss 48-53, 113G-113M), or to format-shifting (ss 43C, 47J, 109A, 110AA) or time-shifting (s 111).

20 Canterbury Park Racecourse Co Ltd v Hopkins (1932) 49 WN (NSW) 27, 29 (Long Innes J); Hawkes and Son (London) Ltd v Paramount Film Service Ltd [1934] 1 Ch 593, 608 (Romer LJ).

21 See Ralph S Brown, 'Civil Remedies for Intellectual Property Invasions: Themes and Variations' (1992) 55(2) Law and Contemporary Problems 45, 47; KJ Greene, 'Motion Picture Copyright Infringement and the Presumption of Irreparable Harm: Toward a Reevaluation of the Standard for Preliminary Injunctive Relief' (1999) 31(1) Rutgers Law Journal 173, 193-4; Pamela Samuelson and Krzysztof Bebenek, 'Why Plaintiffs Should Have to Prove Irreparable Harm in Copyright Preliminary Injunction Cases' (2010) 6(1) I/S: A Journal of Law and Policy for the Information Society 67.

22 Cardile v LED Builders Pty Ltd (1999) 198 CLR 380, 396 [32] (Gaudron, McHugh, Gummow and Callinan JJ). See generally Tagget $v$ Sexton (2009) 255 ALR 522.

23 London and Blackwall Railway Co v Cross (1886) 31 Ch D 354, 369 (Lindley LJ); Irving v Emu \& Prospect Gravel \& Road Metal Co Ltd (1909) 26 WN (NSW) 137, 137 (Street J); DPP v Jones [1999] 2 AC 240; Castlemaine Tooheys Ltd v South Australia (1986) 161 CLR 148, 153 (Mason ACJ). Warner Bros Pictures Inc v Nelson [1937] 1 KB 209, 220-1 (Branson J). Angelides v James Stedman Henderson's Sweets Ltd (1927) 40 CLR 43, 66 (Isaacs ACJ).

26 See, eg, Beswicke v Alner (1925) 31 ALR 482; Goodson v Richardson (1874) LR 9 Ch App 221; Cooper v Crabtree (1882) 20 Ch D 589, 593 (Jessel MR). 
is not deprived of their possessory interest - is notoriously difficult to calculate, ${ }^{27}$ and because intellectual property is generally treated in accordance with property rules. As outlined in Calabresi and Melamed's influential article, property rules protect entitlements through exclusive rights and the ability to enjoin unauthorised uses, whereas liability rules afford compensation to the owner after the entitlement has been used or destroyed (damages). ${ }^{28}$ Because the exclusivity granted under copyright is analogised to rights in physical property and protected under property rules, courts generally presume irreparable harm upon a showing of infringement that justifies the grant of an injunction to restrain the interference. ${ }^{29}$

Both courts and scholars have questioned the application of property rules to intellectual property infringement cases. ${ }^{30}$ In the United States, the Supreme Court broke with established practice in Ebay Inc $v$ Mercexchange $L L C,{ }^{31}$ by refusing to grant an injunction as a matter of course in a patent infringement case. The court held that there was no presumption of irreparable harm for patent infringement, and that a plaintiff must establish a need for injunctive relief under traditional equitable principles. ${ }^{32}$ Specifically, the Court held that a plaintiff must establish four factors:

(1) that it has suffered an irreparable injury; (2) that ... monetary remedies ... are inadequate ...; (3) that, considering the balance of hardships between the plaintiff and defendant, a remedy in equity is warranted; and (4) that the public interest would not be disserved by a permanent injunction. ${ }^{33}$

This reasoning has since been applied to copyright infringement cases. ${ }^{34}$ As some courts have moved away from presuming irreparable harm in intellectual property ('IP') cases, scholars have turned to the question of whether the concept of harm might play a more meaningful role in copyright actions. ${ }^{35}$ Christina Bohannan has noted how difficult it is for courts to "measure or weigh, in individual cases, the value of enforcing a copyright against the value of allowing the use' ${ }^{36}$ She states that this is a modern quandary, arguing that, historically, the

27 Trotter (n 14) 221 (discussing the literature concerning whether downloads or unlawful distribution of copyright material necessarily equates to lost sales).

28 Calabresi and Melamed (n 8) 1092.

29 See Andrew Spillane, 'The Continuing Vitality of the Presumption of Irreparable Harm in Copyright Cases' (2011) 15(1) Marquette Intellectual Property Law Review 257; David McGowan, 'Irreparable Harm' (2010) 14(2) Lewis and Clark Law Review 577.

30 See, eg, JT International SA v Commonwealth of Australia (2012) 250 CLR 1. Gummow J discussed the treatment of trademarks as property: at 50; Mark A Lemley and Philip J Weiser, 'Should Property or Liability Rules Govern Information?' (2007) 85(4) Texas Law Review 783; Christina Bohannan, 'Copyright Harm and Injunctions' (2012) 30(1) Cardozo Arts and Entertainment Law Journal 11 ('Injunctions').

31547 US 388 (2006).

32 Ibid 391-4 (Thomas J for the Court) (2006).

33 Ibid 391 (2006).

34 See, eg, Salinger v Colting, 607 F 3d 68, 75-8 ( $2^{\text {nd }}$ Cir, 2010) (in which, interestingly, the judgment was delivered by Circuit Judge Guido Calabresi); Perfect 10 Inc v Google Inc, 653 F 3d 976, 979-81 (Ikuta CJ) $\left(9^{\text {th }}\right.$ Cir, 2011).

35 The notion of copyright harm has been considered most extensively by United States ('US') legal scholars, and for this reason we refer quite heavily to US literature in this part.

36 Christina Bohannan, 'Copyright Harm, Foreseeability and Fair Use' (2007) 85(5) Washington University Law Review 969, 973 ('Fair Use'). 
impact of infringement was much easier to measure because copyright granted only limited rights to protect against verbatim or close copying - copying, in other words, that was likely to cause direct and material harm to the copyright owner but did not prevent the creation of derivative works. ${ }^{37}$ Bohannan, among others, ${ }^{38}$ has argued that courts should be required to consider harm in the ordinary course of determining copyright infringement. For Bohannan, uses that are clearly harmful are those that substitute for the original work by supplanting the copyright owner's expected markets. ${ }^{39}$ Harm is less apparent for highly transformative uses or for personal uses, ${ }^{40}$ or where the work is exploited in remote markets, which are markets that the copyright owner has chosen not to exploit or is unlikely to exploit. ${ }^{41}$ Christopher Sprigman, too, has argued that copyright law must be based on a theory of harm tied to author's incentives; he writes, "we must understand the kinds of uses that cause significant harm to authors' incentives, and those that do not, so that we might focus on regulating the former and not the latter' ${ }^{42}$ In an Australian context, as we will see below, we would also add consideration of harm to authorial integrity, in addition to the author's economic incentives.

Few Australian courts have directly considered the notion of copyright harm, and they rarely make explicit their reasoning behind calculations of monetary damages. ${ }^{43}$ In one recent case, Dallas Buyers Club LLC v iiNet Ltd [No 4], Justice Perram of the Federal Court refused to permit copyright owners to claim from alleged online file-sharers: a worldwide BitTorrent distribution licence fee, and punitive damages based on the number of other copyrighted works (aside from the particular film in question) that had been downloaded by the alleged infringer. ${ }^{44}$ His Honour held that these claims were speculative and untenable..$^{45}$ Instead, Justice Perram would only allow rights-holders to send letters to individuals claiming for: the cost to purchase a single copy of the relevant film; and the costs

37 Ibid 970, 975.

38 Bohannan, 'Fair Use' (n 36); Christina Bohannan, 'Copyright Infringement and Harmless Speech' (2010) 61(5) Hastings Law Journal 1083 ('Copyright Infringement'); Bohannan, 'Injunctions' (n 30);

Christopher Sprigman, 'Copyright and the Rule of Reason' (2009) 7(2) Journal on Telecommunications and High Technology Law 317; Shyamkrishna Balganesh, 'Foreseeability and Copyright Incentives' (2009) 122(6) Harvard Law Review 1569.

39 Bohannan, 'Copyright Infringement' (n 38) 1134.

40 Personal uses will not usually cause harm, because transaction costs are often prohibitive, relative to the value of the use, so a person is more likely to forgo the use than to pay the costs for licensing the use: see Bohannan, 'Copyright Infringement' (n 38) 1135, 1152, 1158; Bohannan, 'Fair Use' (n 36) 973-4, 10068,1016 .

41 The clearest example of this scenario is Castle Rock Entertainment v Carol Publishing Group Inc, $150 \mathrm{~F}$ 3d 132 ( $2^{\text {nd }} \mathrm{Cir}$, 1998) where a Seinfeld trivia book was found to be infringing, notwithstanding evidence that the copyright owners had consciously decided not to exploit the market for trivia books: see 136, $138,145-6$ (Walker CJ) ( $2^{\text {nd }}$ Cir, 1998). See also Perfect 10 Inc v Amazon.com Inc, 508 F 3d 1146 (9 (th $^{\text {th }}$ Cir, 2007) where Ikuta CJ declined to find market harm, because Google's use of thumbnail images for search served an entirely different purpose than the original images: at $1165-6$ ( $\left.9^{\text {th }} \mathrm{Cir}, 2007\right)$, and because Google's market was remote from the plaintiff's intended markets: at 1168 ( $9^{\text {th }}$ Cir, 2007). 
incurred by the plaintiff in obtaining the alleged infringer's contact details. ${ }^{46}$ This was not a typical copyright infringement case, and these determinations were not made as part of an assessment of remedies. Nevertheless, Justice Perram's judgment was a clear message to rights-holders that they should only be claiming for harms clearly and directly attributable to the copyright infringement at issue. ${ }^{47}$

We argue that where economic harm cannot be identified, it should not be presumed in all infringement cases. Of course, where economic harm is apparent, even if it cannot be precisely quantified, an injunction and damages will likely be an appropriate remedy. Likewise, where there is a clear breach of moral rights then an injunction may also be appropriate. But where there is no evidence of economic harm and no breach of moral rights, a court should not presume economic harm where it does not clearly exist. In these situations, no more than nominal damages should be awarded. For many types of non-substitutive works, including transformative works, there is likely to be no or only trivial economic harm to the copyright owner.

\section{B Australia's Moral Rights Regime}

Australia introduced moral rights in 2000 following an extensive period of debate and a lengthy reform process that involved a number of government reviews. ${ }^{48}$ The moral rights provisions are set out in Part IX of the Copyright Act 1968 (Cth), and apply to individual creators only (not corporations). ${ }^{49}$ In 2004, moral rights protections were extended to performers, such as actors and singers in theatre performances and musical concerts. ${ }^{50}$ Moral rights protections last for the duration of copyright (generally, the life of the author plus 70 years) and cannot be assigned. ${ }^{51}$ While the enforcement of moral rights can be waived in particular circumstances, ${ }^{52}$ the general consensus is that moral rights cannot be waived absolutely in Australia. ${ }^{53}$ For individual creators, this is an important feature of the moral rights protections, especially since for other aspects of copyright

46 Ibid 705-6 [15]-[18].

47 See also Kylie Pappalardo and Carrick Brough, 'Dead Cats in the Mail: Dallas Buyers Club and the Emergence of the User in Australian Intermediary Copyright Law' in John Gilchrist and Brian Fitzgerald (eds), Copyright, Property and the Social Contract: The Reconceptualisation of Copyright (Springer, 2018) 241.

48 See generally the parliamentary debates surrounding the introduction of the Copyright Amendment (Moral Rights) Bill 2000 (Cth): Commonwealth, Parliamentary Debates, House of Representatives, 8 December 1999, 13026-8 (Daryl Williams); Commonwealth, Parliamentary Debates, House of Representatives, 30 October 2000, 21647-59; Commonwealth, Parliamentary Debates, House of Representatives, 31 October 2000, 21714-16 (Daryl Williams); Commonwealth, Parliamentary Debates, Senate, 7 December 2000, 21060-7; Explanatory Memorandum, Copyright Amendment (Moral Rights) Bill 1999 (Cth). See also Elizabeth Adeney, 'Australia: Developments Towards the Current Law' in Elizabeth Adeney (ed), The Moral Rights of Authors and Performers: An International and Comparative Analysis (Oxford University Press, 2006) 541.

49 Copyright Act $\mathrm{s} 190$.

50 See ibid pt IX divs 2A, 3A, 4A. These provisions were added to the Copyright Act by the US Free Trade Agreement Implementation Act 2004 and came into effect in 2007.

51 Copyright Act ss 195AM, 195AN (authors' rights), 195ANA, 195ANB (performers' rights).

52 Ibid pt IX div 6 ss 195AW, 195AWA, 195AXJ.

53 See Elizabeth Adeney, 'Australia's Experience of Moral Rights' (Conference Paper, Moral Rights and New Technologies: Creativity and Authorship in a Digital World, 31 March 2017). 
management there is often an uneven bargaining position in negotiating contracts with publishers and other intermediaries, and creators may be compelled to assign their economic rights. ${ }^{54}$

Under Australian law, individual creators may assert their right to be attributed as the author of a work (section 193), the right not to have authorship of their work falsely attributed (section 195AC), and the right of integrity of authorship (section 195AI). This last right is the most complicated and usually the least understood by the creative community. The right of integrity is defined in the Copyright Act as the right not to have the work subject to derogatory treatment. ${ }^{55}$ 'Derogatory treatment', in turn, is defined as a material distortion of, mutilation of or material alteration to a work, or doing anything in relation to a work that is prejudicial to the author's honour or reputation..$^{56} \mathrm{~A}$ straightforward reading of this definition seems to impute a subjective assessment into the definition of 'derogatory treatment', such that if an author perceives a slight to their honour or reputation their moral right of integrity will be infringed. But it is not this simple. Section 195AS inserts a requirement that the treatment of a work also be unreasonable the section provides that there will be no infringement of the right of integrity if the action or treatment was reasonable in the circumstances, taking into account various factors such as the nature of the work and the context in which is what used. The result is that 'derogatory treatment' is both a subjective and objective test, and one that is not easily determined..$^{57}$

Reasonableness is also a feature of the moral right of attribution. Section 195AR provides that it is not an infringement of the author's right of attribution if it was reasonable in all the circumstances not to identify the author. ${ }^{58}$ This provision allows some flexibility in the application of moral rights dependent on the type of work and the type of use. For example, what will be a reasonable attribution with respect to use of an artwork on a billboard is likely to be very different to what a reasonable attribution looks like for quoting from a literary work in a book or research article.

There is very little case law on moral rights provisions in key common law jurisdictions, though this is perhaps not so surprising. ${ }^{59}$ Moral rights are designed

54 Ruth Towse, 'Copyright and Cultural Policy for the Creative Industries' in Ove Granstrand (ed), Economics, Law and Intellectual Property: Seeking Strategies for Research and Teaching in a Developing Field (Springer-Science+Business Media, 2003) 419.

55 Copyright Act $\mathrm{s} 195 \mathrm{AI}(2)$.

56 Ibid ss 195AJ, 195AK, 195AL.

57 See Nicolas Suzor, 'Where the Bloody Hell Does Parody Fit in Australian Copyright Law?' (2008) 13(2) Media and Arts Law Review 218, 246; Maree Sainsbury, Moral Rights and Their Application in Australia (Federation Press, 2003) 55-9.

58 Subsections (2) and (3) of section 195AR of the Copyright Act list a series of matters to be taken into account when determining whether it was reasonable in the circumstances not to identify the author, including: the nature of the work; the purpose for which the work was used; the manner and context in which the work was used; industry practice; and any difficulty or expense that would have been incurred as a result of identifying the author.

59 See the second reading speech for the Copyright Amendment (Moral Rights) Bill 1999 (Cth): Commonwealth, Parliamentary Debates, House of Representatives, 8 December 1999, 13026 (Daryl Williams, Attorney-General) (explaining that 'enforcement of moral rights through the courts will be an exceptional occurrence': at 13027). In Australia, cases include Meskenas v ACP Publishing Pty Ltd 
for individual creators, who may not have the financial means to instigate costly court action against infringers. Most copyright infringement cases that reach the courts involve, on at least one side, large commercial actors with the economic means to initiate and sustain litigation. Further, moral rights infringement does not typically lead to significant monetary remedies. ${ }^{60}$ Particularly in the case of missing or incorrect attribution, the best remedy may simply be to rectify the omission or mistake. This can often be achieved through asking; in practice, this is typically handled without litigation. Nevertheless, our empirical research reveals that moral rights protections are extremely important to both Australian creators and copyright users. As discussed further below, we propose that moral rights might be given more weight within the copyright system by being considered as part of the determination of remedies in infringement cases. This is one way in which the notion of copyright harm - as understood and articulated by creators can be better acknowledged and given meaning in light of the discretionary nature of equitable remedies. ${ }^{61}$

\section{QUALITATIVE METHODS}

This paper presents qualitative empirical research with Australian creators and copyright consumers. Our goal was to better understand how copyright harm is conceptualised and experienced in practice. This is particularly pertinent for creators who are working with culture as part of their everyday practice. The documentation of everyday experiences helps to inform the determination of whether copyright infringement should be treated under a property rule (where irreparable harm is presumed) or a liability rule (where it is not).

Between November 2016 and April 2017, we conducted semi-structured interviews with self-identified Australian creators and consumers. We used snowball sampling to recruit participants, through word-of-mouth and email. Creators came from a variety of artforms, including: documentary filmmakers; literary authors; musicians, including composers, DJs and sampling artists; 'VJs' (creators who sample visual material as well as sounds); YouTube creators and video remix artists; and visual artists, including street artists. The creators we spoke to had various levels of expertise, ranging from emerging creators (less than five years' experience in their relevant field) to established creators (more than 20 years' experience in their field and an established reputation). ${ }^{62}$ In our creator

(2006) 70 IPR 172 (concerning attribution) and Perez v Fernandez (2012) 260 FLR 1 ('Perez') (concerning integrity).

60 Unlike in Perez (2012) 260 FLR 1, where the plaintiff was awarded \$10,000 for infringement of his moral right of integrity: at 19 [107] (Driver FM). Importantly, the large damages award seemed mostly driven by two considerations: the fact that the song had not yet been released in Australia, and that the defendant had 'benefited by falsely representing a positive association between himself and Mr Perez': at 12 [69], 15 [86] (Driver FM).

61 We understand that plaintiff copyright owners will not always be 'creators' and may instead be corporate entities with wholly commercial interests. We focus in this article on cases involving creators.

62 For a more detailed breakdown of interviewee demographics, see Kylie Pappalardo et al, Imagination Foregone: A Qualitative Study of the Reuse Practices of Australian Creators (Report, November 2017). 
sample, there were 10 participants who identified as female and 19 participants who identified as male. The consumers we interviewed self-identified as individuals who regularly used social media and engaged with creative content online. In our consumer sample, there were 11 participants who identified as female and 5 participants who identified as male. None of our participants identified as Aboriginal or Torres Strait Islander.

Creators were interviewed individually, and consumers were interviewed in groups of two to six people to support ongoing discussion and conversation. Interviews typically ran for between 40 and 90 minutes. Interviews with creators were conducted either in-person (in Brisbane, Sydney and Melbourne) or via Skype for those participants located rurally or in Perth. The consumer interviews were all held in Sydney.

During the interviews, participants were asked open-ended questions about their understanding of copyright, the importance of copyright, whether they had sought permission to use or redistribute creative work, and what the process for getting permission was like for them. They were also asked about their response if they were refused permission. Interviews were recorded and transcribed. We then conducted thematic analysis of the data collected. We coded for themes around participants' understanding of the law, practices of re-use, experience with copyright licensing, reliance on copyright exceptions, problems encountered in reuse, and responses to problems encountered. The participants interviewed all had some experience with reusing existing content, whether through using samples or snippets in music or film, appropriation art, remix, or quotation. For this reason, our study is not representative of all creators or all stakeholders in copyright law, particularly copyright owners.

We are conscious that identifying our participants as consumers or creators sets up an unproductive (and unrealistic) binary between the two participant groups. Recent work on relationality and copyright has pointed out that arbitrarily understanding authors, users, consumers and infringers as separate actors is not a conceptually sound approach. ${ }^{63}$ Therefore, while we asked individuals to selfidentify as either creators or consumers, we approached these categories as malleable and, indeed, our data supported this conceptual approach. We found that people actually engaged in a wide variety of practices from creation to infringement, regardless of how they viewed themselves. Creators used copyrighted work in ways that might be deemed consumptive, and consumers engaged in ordinary (or vernacular) creative practice. ${ }^{64}$ This ultimately speaks to the results of our data, which showed that both participant groups had very nuanced understandings of what it means to create, use and infringe copyrighted works. Importantly, the attitudes and behaviours of both groups coalesce around a series of practices that directly align with the moral rights provisions in the Copyright Act.

63 See Carys J Craig, Copyright, Communication and Culture: Towards a Relational Theory of Copyright Law (Edward Elgar, 2011); James Meese, Authors, Users, and Pirates: Copyright Law and Subjectivity (MIT Press, 2018) ('Authors, Users, and Pirates').

64 See Jean Burgess, 'Hearing Ordinary Voices: Cultural Studies, Vernacular Creativity and Digital Storytelling' (2006) 20(2) Continuum: Journal of Media and Cultural Studies 201. 


\section{RESPECTFUL RE-USE: AUSTRALIAN CREATORS AND RE- USE NORMS}

Within copyright scholarship, qualitative data from creators is scarce. ${ }^{65}$ There are some exceptions in the United States, such as research by Professor Jessica Silbey, which demonstrates that intellectual property owners value their 'autonomy and identity' and 'relationships (between people, among audiences, and within a community)' often more than they worry about small-scale infringements of their work. ${ }^{66}$ Silbey conducts in-depth, face-to-face interviews with artists, scientists and engineers, and their lawyers, agents and business partners, to understand their lived experiences with creating and innovating, and how intellectual property law intervenes in their lives. ${ }^{67}$ Silbey observes that artists and business persons often have a particular tolerance for copyright infringement. ${ }^{68}$ She posits that this tolerance exists because creators understand that their own creative processes involve a complex mix of originality and re-use, sometimes through infringement. ${ }^{69}$ In fact, she notes that '[i]nterviewees struggled to draw a line between their own contribution to the final work and works from which they borrowed in their field'. ${ }^{70}$ Thus, tolerating infringement was a way of 'making room for play and experimentation ... a precursor to the act of creation or discovery'. ${ }^{71}$

In our own empirical work, we found that a similar set of values emerged. Creators placed a strong emphasis on the granting and receiving of 'respect' between and amongst creators, which almost always entailed, at a minimum, attribution. With the exception of one street artist who operated anonymously, all of the creators we interviewed indicated that giving and receiving attribution was central to their creative practice. ${ }^{72}$ An interactive media creator stated, 'I'm very conscious that credit is given where credit is due'. 'We always credit the work', said one creator. 'It's just good old-fashioned etiquette', another said. A DJ

65 For qualitative studies in Australia, see Andrew T Kenyon and Robin Wright, 'Whose Conflict? Copyright, Creators and Cultural Institutions' (2010) 33(2) University of New South Wales Law Journal 286; Matthew Rhys Rimmer, 'The Pirate Bazaar: The Social Life of Copyright Law' (PhD Thesis, University of New South Wales, 2001). In the United States, see Jessica Silbey, The Eureka Myth: Creators, Innovators and Everyday Intellectual Property (Stanford University Press, 2014) ('The Eureka Myth'). See also studies by Patricia Aufderheide and Peter Jaszi, as discussed in Reclaiming Fair Use: How to Put Balance Back in Copyright (University of Chicago Press, $2^{\text {nd }}$ ed, 2018).

66 Silbey, The Eureka Myth (n 65) 153.

67 See ibid; Jessica Silbey, 'Harvesting Intellectual Property: Inspired Beginnings and "Work-MakesWork," Two Stages in the Creative Processes of Artists and Innovators' (2011) 86(5) Notre Dame Law Review 2091; Jessica Silbey, 'IP and Ethnography: A Qualitative Research Approach' in Irene Calboli and Lilla Montagnani (eds), Oxford Handbook on Intellectual Property Research (Oxford University Press, 2019).

68 Jessica Silbey, 'Fairer Uses’ (2016) 96 Boston University Law Review 857, 860.

69 Ibid 859-61.

70 Silbey, The Eureka Myth (n 65) 46.

71 Ibid 45.

72 Pappalardo et al (n 62) 31. See also Patricia Aufderheide et al, 'Calculating the Consequences of Narrow Australian Copyright Exceptions: Measurable, Hidden and Incalculable Costs to Creators' (2018) 69 Poetics 15 . 
musician elaborated on the link, for her, between attribution, honesty and relationship-building:

It's fine when you credit it, because then it puts it into context. But without that you're creating a false presentation, I think, when you do that. I think that's a big I would hate to piss off any of my heroes from the ' 80 s that are still $-\mathrm{a}$ lot of them are still around, still producing.

In general, creators also expected the same courtesy to be extended to them if their work was re-used by someone else. Commonly expressed sentiments included: 'I would expect, at a minimum, attribution, most definitely', and 'I'd want to be attributed. That's pretty important'.

Our data also supported Silbey's findings that creators often have a level of tolerance for copyright infringement, particularly non-substitutive uses. For example, the front-person of a well-known band told us, when discussing other people sampling the band's music: 'Our old record label at one point wanted to sue someone and we were just like, you're crazy. Like what are you doing? We're not comfortable with that at all'.

The interviewee indicated that while they had no problem with users sharing or building upon their music, they would expect credit to be given back to the band. Similarly, other creators variously stated:

For me, the line's drawn where - if someone's taken your work, as it is, in saying that it's theirs completely - straight plagiarism. But I'm open to - yeah, various forms of sampling and what not.

I wouldn't want to think that somebody else was getting the credit for my work either. I'm very - I'm happy to be acknowledged. I've never said no to anybody if they'd wanted to either quote from an article I've written or sometimes even reproduce an article I've written or a piece of music.

It's not always necessarily about money and distribution. It can be, well, you know you've got to credit me properly so people know where it's come from.

So I'm not being too strict with copyright. I'm happy with re-distributions of my work if there's a credit in there and I get some growth. That's usually all I'll chase people up for and ask about.

The word 'plagiarism' arose repeatedly in our interviews, indicating that our interviewees were less concerned about their content being re-used per se and more concerned about the erasure of their artistic identity through unattributed use. 'Plagiarism' is a very different word from 'stealing', which is sometimes used within the literature and in industry to stress the framing of copyright interests as property with the associated property-based remedies for infringement. ${ }^{73}$

Even more than attribution, though, creators were anxious to ensure that their re-use practices were respectful to other creators in their field. 'Respect' is a tricky concept, but arguably no more so than 'integrity of authorship' in the moral rights provisions of the Copyright Act. The norms that creators follow to show each other 'respect' may, in fact, be the closest thing we have to the moral right of integrity operating in practice. Norms are likely to differ slightly between different artforms and industries, but there are commonalities too. For the creators we interviewed,

73 Patricia Loughlan, "'You Wouldn't Steal a Car ...": Intellectual Property and the Language of Theft' (2007) 29(10) European Intellectual Property Review 401; Peter K Yu, 'Digital Copyright and Confuzzling Rhetoric' (2011) 13(4) Vanderbilt Journal of Entertainment and Technology Law 881, 891. 
'respectful' re-use of a work was partly contingent on the level of transformativeness of the use and the subsequent creativity employed. Most creators were happy for another person to re-use or remix their work, provided that the uses employed some creativity and were not blatant 'rip offs' ${ }^{74}$ In other words, the use should not be an attempt to use the work as is without further creative input (unless permission is obtained) and should not be an attempt to pass off the work as the user's own. Even where the use was done without authorisation, many creators were not concerned so long as the subsequent use was transformative. This sentiment was consistent across all artforms. An online content creator told us, 'If there was an intent to have a conversation with the work and continue the work in some way rather than trying to pretend as if it's their own, I'd have no problem with it. I would be flattered that someone wanted to do that'. Other creators also expressed this notion that creative re-use was flattering rather than concerning. An author said, 'In some ways I think I would be more flattered than annoyed about that. If someone actually took the time to read [my work] and was so affected that they had to create something from it that would actually be an amazing outcome from a work'. ${ }^{75}$

For musicians and sampling artists, respectful re-use also required a willingness to have difficult conversations about whether the use of a particular sample detracted from the original work. The emerging artists we interviewed indicated that they would willingly remove their own remixes from the internet if the artist that they sampled contacted them to express unhappiness with the work. The norm, as expressed to us, was that re-use without permission was acceptable so long as good faith efforts were made to do justice to the original and there was space, after the fact of the use, to have conversations with the original artists about whether the remix was respectful. A musician explained, 'If [the original creator was] saying they weren't down with it, I would - I'd be like, I need to step my game up. That's a positive outcome. ... I wouldn't want to devalue the music that I'm sampling'.

Creators presented a notion of 'respectful re-use' that was more nuanced than requiring only favourable uses. In other words, 'respect' did not necessarily exclude uses that were critical of the original or which employed parody or satire. What mattered was that the use served a deeper creative purpose than free-riding, and that the use was not done in bad faith. Again, creators used principles of transformative-ness and facilitating ongoing dialogue with the original artwork or creator as a means of distinguishing between proper and improper re-use. An online content creator said to us, in the context of complaining about improper copying of their own works: 'I think the distinction has to be made between the way we're using content - which is parody and satire, and using elements of an original and transforming it into something else - and what is happening to us, which is people just taking the entire content'. Several interviewees had stories of their own works being copied, wholesale, for another's commercial gain, such as artwork being printed onto t-shirts or dresses and sold to members of the public

74 Pappalardo et al (n 62) 33-5.

75 Ibid 34. 
without permission. Interviewees told us that this behaviour was never acceptable, and was most definitely disrespectful. ${ }^{76}$

We asked creators whether they considered commercial uses to be more problematic than non-commercial uses. No creator indicated that a person should never make money from re-use. However, many differentiated between large-scale commercial uses or uses that generated significant revenue, on the one hand, and uses by small-scale artists or organisations, or which generated only small sums of money, on the other. ${ }^{77}$ Most were unconcerned by uses of their work that derived only small amounts of money, even if the user had not sought permission for the use. The following exchange was typical in our interviews:
Facilitator:
Does money change things for you, if they were making money off of it would that change things?
Interviewee:

$$
\begin{aligned}
& \text { Yeah, I guess it would but only if they were making heaps of } \\
& \text { money. Yeah if it was not much money then I wouldn't really } \\
& \text { care about it either. }
\end{aligned}
$$

Copyright law is premised on the principle of authorised use - that is, permission before re-use. ${ }^{78}$ However, the creators we interviewed struggled with obtaining prior permission for re-use, largely because the processes for licensing works can be time-consuming, expensive and counter-intuitive. Publishers and large commercial copyright owners often require paperwork to be completed to request permission, and this paperwork can be long and complicated. Many creators complained about the time taken to request and negotiate licences; experienced creators reported that they generally expect to invest months in this process, even for very small samples and straightforward uses. Even after this investment of time, many large rights-holder organisations never responded to emails or requests for permission, or they simply denied permission without providing reasons or options for adjustment. Creators told us that they felt disrespected by this, and that this impersonal and lengthy system for seeking permission was disruptive and detrimental to their creative process. They wanted to create and to be driven by their creativity - not be chasing their tails seeking permissions for minor uses. Creators also felt that the legal permissions system contradicted, in many ways, the kinds of respectful re-use and artist-to-artist conversations that they were seeking. "[The] whole process of the politeness of asking is not facilitated', one creator said. 'There's nothing polite about all of these forms and all that sort of stuff ${ }^{79}$ Creators preferred, in general, to make use of a work first, and then have a discussion about the use with the copyright owner or original artists later, if necessary. At that point, the creator would be in a better position to explain how their own use builds upon the previous work, or transforms it; what they have done to exhibit respect (including attribution); and whether the use is expected to generate revenue (unlikely, but possible).

$76 \quad$ Ibid 35.

77 See also Kenyon and Wright (n 65) 295, which found a similar emphasis on commercial uses by creators: ' $[\mathrm{T}]$ he point that appeared to distinguish whether payment was seen as being necessary or not, for many of our respondents from both the creator and institutional sectors, was the concept of commercial use'.

78 Copyright Act ss 36(1), 101(1). See also Wu (n 5) 618.

79 Pappalardo et al (n 62). 


\section{CREDIT AND CIRCULATE: CONSUMER DISTRIBUTION OF ONLINE CONTENT}

Our interviews with consumers focused on low-level copying and sharing that generally does not interfere with copyright owners' licensing markets. The types of uses that our consumer interviewees engaged in included making and sharing memes (which might include copyrighted images or snippets of video), ${ }^{80}$ and posting content to personal social media pages (eg, on Facebook or Instagram). Our interviews revealed that consumers saw attribution as an important ethic, but one that was hard to enact in practice. Participants noted that in an online environment where content circulated freely, making sure a creator was named was vital. When asked whether the original creator of an image or video seen online mattered, a typical initial response from a participant was that if they could find the original source they would 'always credit it'. Expanding on this requirement to attribute, another participant noted a disquiet with sharing unattributed content, saying: '[I]f I stole a girl's funny quote or her image and made out that I was there or something ... I don't know, I just wouldn't do that'. Some participants went into further detail and made reference to attribution standards on different social media platforms, such as the 'bookstagram' community on Instagram (organised around the hashtag \#bookstagram). One participant explained the attribution model that operated in this community:

What a lot of people will do is they'll put their handle on their photos but they'll also do things where you can regram their photos for promotion, so the thing is you're ... using their photo as a ... self-promoting kind of thing but also they're okay with it.

These responses signalled attribution as a critical part of the online infrastructure and a practice that had found its way into numerous online communities.

Despite the acknowledged importance of attribution, there was some contestation amongst participants about its precise role. A vocal minority felt that simply providing attribution did not authorise further distribution, particularly when one considered the growing commercial viability of curated meme pages on Instagram. Another participant noted that some content hubs explicitly require people to submit original content, and that they paid for content featured on their Facebook page. However, when discussing recirculation by audience members, the majority of consumer respondents argued that as long as they attributed work, they should be able to circulate it. Many linked this view on copyright law to the overall operation of the internet, explaining 'the internet [was sold as] this place of free content and free expression' and that 'you put it on the web and it's there

80 '[I]n contemporary popular usage an internet "meme" is a faddish joke or practice (like a humorous way of captioning cat pictures) that becomes widely imitated': Jean Burgess, "'All Your Chocolate Rain Are Belong to Us?": Viral Video, YouTube and the Dynamics of Participatory Culture' in Nikos Papastergiadis and Victoria Lynn (eds), Art in the Global Present (UTS ePress, 2014) 86, 87; 'The term "meme" was coined by biologist Richard Dawkins in his book The Selfish Gene (1976) to refer to small cultural units of transmission, analogous to genes, which are spread by copying or imitation': Limor Shifman, 'An Anatomy of a YouTube Meme' (2011) 14(2) New Media \& Society 187, 188. See also Limor Shifman, Memes in Digital Culture (MIT Press, 2014). 
to be shared'. The dominance of this approach could also be linked to the strong attribution norms found in online communities, ${ }^{81}$ with participants citing attribution practices on Instagram and Tumblr as models, where professional and amateur creators use attribution mechanisms to tacitly endorse sharing and the ongoing circulation of content.

However, as the interviews continued, participants conceded that the practicalities of attribution online raised a number of issues, which meant that their redistribution of content did not always match up with their idealised practices. One noted that the interfaces of many social media platforms were not set up to support attribution, which caused them to often forget to properly credit the content they were sharing:

[T] he way it's set up you don't think about copyright. You're not consciously going, 'Oh should I-' Or at least I'm not consciously going, 'Should I credit this person in what they do?' It's just you're actively consuming content, and there's so much content there that the copyright and the crediting of someone who created that content is so minimal to what you're consuming so it just falls to the wayside.

Another participant highlighted the difficulties involved with using copyright images. He explained that the simple production of posters for a club night, which used scans of 1980s music magazines from Flickr raised a lot of questions around attribution, which he could not answer. Who got the credit? Was it 'the guy that scanned the magazine and posted it, or is it the magazine that's no longer in business? Where did these scans come from in the first place? Did Flickr need a shout-out?' Others noted that some forms of content did not seem to require attribution, explaining that in their opinion 'when people create these memes they don't actually expect to be credited'. A participant asked, '[when you're] trying to be light-hearted and funny ... do you need to credit that when it's so far removed from where it started?'

In the case of memes, we could see a lay understanding of 'reasonableness' emerge, with some participants making judgments about what was seen to be reasonable attribution in the context of a particular work. While participants had strong opinions about attributing content, memes stood as a notable outlier for certain participants, who suggested that attribution was not required. Such an approach shows that these individuals carried an understanding of the context in which a work was created and were able to articulate a standard of reasonableness as a result. Indeed, it shows that while consumers struggle with attribution, their values align with the reasonableness defence, incorporating a range of issues including the nature, purpose and context of the work in addition to established practice. ${ }^{82}$ In an ideal world, our participants would aim to attribute most online creative works, with a subset suggesting that this would not be required for remixable content like memes.

81 Katharina Freund, "Fair Use is Legal Use": Copyright Negotiations and Strategies in the Fan-Vidding Community' (2016) 18(7) New Media \& Society 1347, 1356-8; Sal Humphreys, 'The Challenges of Intellectual Property for Users of Social Networking Sites: A Case Study of Ravelry' (Conference Paper, Mind Trek, 7-9 October 2008); Dan Perkel, 'Share Wars: Sharing, Theft, and the Everyday Production of Web 2.0 on DeviantArt' (2016) 21(6) First Monday 6795:1-19

$<$ https://firstmonday.org/ojs/index.php/fm/article/view/6795/5526>. 
Concerns were also raised about the inequities of attribution, infringement and audiences. Creators with large online audiences could actively use their fans to challenge companies who allegedly infringed their copyright or design, or failed to attribute their work. One participant explained, 'Big companies can get called out on social media when the designer is like, "This is mine, and this is what they've done. What do you think, did they rip me off?"' However, as another participant went on to note, 'that doesn't happen for everyone, not everyone has a little fan base that's keeping an eye on what's happening in the interwebs'. Some of our participants were most likely referencing the furore surrounding fashion label Zara, who has repeatedly been accused of copying the designs of smaller artists, most notably Tuesday Bassen. Bassen publicised her complaint against Zara in mid-July 2016 and received a significant amount of support online (her Instagram was regularly receiving between 7,000 and 42,000 likes) ${ }^{83}$ and international press. ${ }^{84}$ Bassen was joined by a number of other independent artists, who banded together and set up Shop Art Theft, which aims to support artists who have allegedly had their work copied. ${ }^{85}$ However, our participants were obviously conscious that other creators might not be able to draw on a similarly strong online community if their work was not as popular, or if the alleged infringer was less prominent.

Indeed, most participants felt that making money from unlicensed copyrighted content was not appropriate. Previous work drawing on the data (conducted by one of the authors), showed that participants 'drew a clear line between noncommercial circulation ... and the commercial exploitation of copyrighted content ${ }^{9}{ }^{86}$ While participants described social media as a place where people could share content freely, they were aware of various power imbalances that could occur between creators and businesses seeking to make money off the back of usergenerated content. In deciding whether uses were appropriate, our participants would weigh up whether the use of content was supporting a creator, was noncommercial and non-substitutive, or was actively harming a creator's potential income stream.

It is also important to consider the relational nature of these consumers and recognise that many of them also use and create content as well as consume it. ${ }^{87}$ As noted in our methods, we divided our participants into groups based on their own self-identification as either creators or consumers in response to specific calls for participation. However, throughout the consumer interviews, participants also indicated that they viewed themselves as creators of content (although not always

83 See tuesdaybassen $($ Instagram) $<$ https://www.instagram.com/tuesdaybassen/?hl=en $>$. Examples of posts with thousands of likes include: tuesdaybassen (Instagram, 20 July 2016)

$<$ https://www.instagram.com/p/BIEGImxgFKe/>; tuesdaybassen (Instagram, 25 July 2016)

$<$ https://www.instagram.com/p/BIP3845DDfX/>.

84 Nicole Puglise, 'Fashion Brand Zara Accused of Copying LA Artist's Designs', The Guardian (online, 21 July 2016) < https://www.theguardian.com/fashion/2016/jul/21/zara-accused-copying-artist-designsfashion>.

85 See shoparttheft, 'About This Blog' Shop Art Theft (Web Page) <http://shoparttheft.tumblr.com/>.

86 James Meese and Jennifer Hagedorn, 'Mundane Content on Social Media: Creation, Circulation, and the Copyright Problem' [2019] (April-June) Social Media + Society 1, 6.

87 See Craig (n 63) 25; Meese, Authors, Users, and Pirates (n 63) 3-4. 
economically viable content) on social media platforms, a position that shaped their views around attribution. For example, an ethic of attribution and respect was clearly articulated in this response to a question about how participants would feel if their content was taken from a social media platform and re-used:

I think for me, if someone's taking something of mine without asking and then saying it's their own, then I'd be pretty mad about that. If they're taking something of mine without asking, but crediting me for it, that's not ideal, but I wouldn't be too fussed about it.

Others repeated the point that their content was online, which meant that it was open to be shared, '[because] if people can access my content and I've set up my privacy settings to allow them to do that, then I've got no issue with it'. With the re-use of their own content largely only becoming problematic when people earned money from it, most participants were happy with others circulating their content so long as it was attributed. They maintained this standard as an ideal approach (albeit not always strictly applied) when working with other people's content.

While participants were, in general, very forthright with their views on attribution, the consideration of their own creativity online did not lead to substantive discussions around the protection of a work's integrity. Only one group interview briefly touched on the use of consumers' own copyrighted works in a derogatory manner, but participants considered these issues to be defamatory and in breach of their privacy, rather than an infringement of their moral rights.

\section{IMPLICATIONS FOR COPYRIGHT LAW AND PRACTICE}

We can draw a number of findings from our empirical studies involving consumers and creators. First, what IP lawyers think of as 'moral rights' - the right to be correctly attributed and the right of integrity - are important to both creators and consumers, though creators generally discuss integrity using the language of 'respect'. Both participant groups thought primarily in terms of norms around attribution and respect when they considered and discussed copying, re-use and sharing of materials. Second, nearly all of our participants expressed preference for respectful, attributed use without prior permission, rather than copyright's current system which requires permission before use. It might seem obvious that consumers would prefer a system where they could use and share copyrighted content for free, without prior licence. But this preference was also true for many of the creators we interviewed, who have much stronger economic interests in copyright's licensing models. We acknowledge that this preference may be more pronounced for the types of creators we interviewed, whose creative practices all involved elements of re-use, than it might be for other, more 'traditional' creators. ${ }^{88}$ Nevertheless, our findings align with the body of theoretical literature that argues that all creativity involves re-use and reconceptualisation. ${ }^{89}$ The creators we

We recognise that some creators and copyright owners may not share the views on copyright re-use and harm reflected in our study.

89 See, eg, Henry Jenkins, Sam Ford and Joshua Green, Spreadable Media: Creating Value and Meaning in a Networked Culture (New York University Press, 2013); Aram Sinnreich, Mashed Up: Music, 
interviewed were highly aware of the recombinant nature of creativity, even if copyright lawyers sometime overlook this feature. Third, our data suggests that a great deal of use without permission is happening anyway, even though such uses are technically infringing and even though some creators and consumers are aware that this is unlawful. In his book, Free Culture, Harvard Professor Lawrence Lessig famously argued that overly strong copyright laws were turning the American public - ordinary citizens doing ordinary things with copyrighted content - into criminals. ${ }^{90}$ Australian copyright law mimics American copyright law in almost every way, except that we do not have the broad fair use exception to infringement that Americans enjoy. In short, our system is even more restrictive for Australian creators and consumers than the United States ('US') copyright system. Australians are already accused of being copyright 'criminals' Australian consumers have some of the highest rates of unlawful downloading in the world. ${ }^{91}$ Efforts by the Australian government and rights-holders to legislate, regulate, coerce or educate away this infringing behaviour have largely failed. ${ }^{92} \mathrm{In}$ this part, we posit a gentler approach - what if we sought to better align law with practice through the determination of copyright remedies? This would not require any changes to the infringement test or any new exceptions, nor would it constrain everyday cultural practices with heavier enforcement. ${ }^{93}$ But it might help to address copyright's legitimacy problem in the digital age. ${ }^{44}$ Below, we outline some of our key ideas for how creator and consumer practices might inform and improve the functioning of copyright law.

\section{A Supporting Tolerated Use}

The copyright uses we have focused on in this article are exactly the types of uses that tend to fall within the space of 'tolerated use' - uses that are either highly transformative but unlicensed, or which are harmless and often banal. Our data indicates that for many creators and users, working within the space of tolerated use is both ordinary and a perfectly reasonable thing to do.

But copyright is a permissions-based game. The risk for users and creators who elect to operate within the realm of tolerated use, therefore, is that at any moment the copyright owner may decide not to be so tolerant. The 'grey zone' may rapidly

Technology, and the Rise of Configurable Culture (University of Massachusetts Press, 2010); Kembrew McLeod and Peter DiCola, Creative License: The Law and Culture of Digital Sampling (Duke University Press, 2011); Joseph Schloss, Making Beats: The Art of Sample-Based Hip-Hop (Wesleyan University Press, 2004); Siva Vaidhyanathan, Copyrights and Copywrongs: The Rise of Intellectual Property and How It Threatens Creativity (New York University Press, 2001).

90 Lawrence Lessig, Free Culture: The Nature and Future of Creativity (Penguin Books, 2004) 205-7.

91 See Attorney-General's Department, Australian Government, 'Online Copyright Infringement' (Discussion Paper, 30 July 2014) $1<$ https://apo.org.au/node/40630>; Dootson and Suzor (n 15).

92 See Attorney-General's Department (n 91). See also Dan Hunter and Nicolas Suzor, 'Claiming the Moral High Ground in the Copyright Wars' in Phillipa McGuinness (ed), Copyfight (NewSouth, 2015) 131. The same is true in the United States: see Mark Lemley, 'IP in a World Without Scarcity' (2015) 90 New York University Law Review 460, 462; William Patry, Moral Panics and the Copyright Wars (Oxford University Press, 2009).

93 It is worth noting, however, that this article is not intended to close off discussion about the merits of a fair use defence or more extensive fair dealing exceptions in Australia.

94 See Dootson and Suzor (n 15) 233-4. 
diminish on a copyright owner's whim. ${ }^{95}$ While tolerated use is so-called precisely because it is rarely litigated, the potential for litigation may nevertheless present enough of a threat to stifle production by some creators. Several of the creators we interviewed in our study spoke of the pervasive anxiety they feel about copyright lawsuits. One filmmaker noted that even though she tries to do the right thing, 'it is one of those crazy fears that you have as a creator that somewhere you've done the wrong thing and you're going to get done for it in terms of copyright'. Another creator described this as an 'inbuilt fear' of getting sued..$^{96}$

While a 'tolerated use' is technically an infringing use, and one that a rightsholder may choose to dispute, it is generally a use that does not cause any clear harm to the copyright owner. As noted earlier, the concept of 'copyright harm' is unsettled and under-developed. Among those who have considered what copyright harm means, there is a consensus that one of the best indications of likely harm is substitutability in the market. ${ }^{97}$ The more that a defendant 'changes the meaning, message or purpose of a work, the less likely the use is to substitute for the copyright owner's work or its most foreseeable derivatives' and the less likely it is that the use will harm the copyright owner. ${ }^{98}$ Thus, in the context of the uses that we describe, we take 'harm' to mean market substitution for the original work. ${ }^{99}$ In most remix and sampling work, and in creations like documentary films or parodies, no substitution for the original occurs. The market for the original work continues unabated and in some cases may even receive a boost because of the reuse. Often, therefore, there may be no financial harm for which a copyright owner needs compensation.

This argument holds in many cases of small-scale infringement of works reproduced in their entirety online through social media platforms. The assumption that every reproduction results in economic loss to the copyright owner is difficult to sustain in a media environment which operates on reproduction and sharing. ${ }^{100}$ An assessment of harm would take into account the significant changes that have occurred in digital media markets, which sees a value and business for creators being generated through individual and algorithmic circulation. Instagram artists, for example, are starting to gain meaningful opportunities through the publication and circulation of their work online. ${ }^{101}$ Brands and major companies are producing content with the aim of it being shared repeatedly, "scattering" content broadly and then "gathering" potential supporters'. ${ }^{102}$ Our consumer respondents

95 Tehranian (n 6) xxi.

96 Pappalardo et al (n 62) 23.

97 See Bohannan, 'Fair Use' (n 36). See also Bohannan, 'Copyright Infringement' (n 38); Sprigman (n 38).

98 Bohannan, 'Fair Use' (n 36) 1006.

99 In accordance with the views expressed by our interviewees, harm might also be occasioned where a substantial part of an existing work is used in a highly commercial venture (one that makes 'heaps of money') without accounting to the original creator: see, eg, Pappalardo et al (n 62) 17. These are also circumstances which can be considered by a court in assessing remedies under a liability rule: see Copyright Act $\mathrm{s} 115$.

100 See Dootson and Suzor (n 15) 223. See also Jenkins, Ford and Green (n 89); Jenny Kennedy, 'Conceptual Boundaries of Sharing' (2016) 19(4) Information, Communication \& Society 461.

101 See, eg, Hannah Keegan, 'The Rise of the Instagram Artist', The Economist (online, 5 October 2017) $<$ https://www.1843magazine.com/culture/the-daily/the-rise-of-the-instagram-artist>.

102 Jenkins, Ford and Green (n 89) 82. 
understood this environment of content consumption and viewed many of their actions as essentially non-commercial reproductions, which did not directly substitute (and in some cases enhanced) the market of the original copyrighted work. Considering that many content producers are working towards 'spreadability', ${ }^{103} \mathrm{a}$ finding of harm would need to take into account the specific market contexts in which the reproduction takes place. In the context of consumption and production through digital and social media, small-scale infringements are unlikely to qualify as harmful.

For uses which do not serve as a substitute for the original work, either because they are minimal or because they are highly transformative, it makes sense to align copyright practice with creative practice - to inject norms into the analysis. ${ }^{104}$ Creators have extremely robust norms about what 'respectful re-use' entails. They are guided by ethical norms relating to attribution; to the degree of commerciality of the re-use; and to the level of creative engagement with the original work, whether through transforming or speaking back to the original work. ${ }^{105}$ Similarly, consumers on social media platforms are acutely aware of attribution norms in using and sharing online content. Our argument is that where creators and consumers engage with existing copyright content in a way that is formally unsanctioned but otherwise in line with norms of practice, they should be permitted some confidence that this respectful re-use will not result in serious legal penalties.

How can this support be achieved as a matter of law? One important and eminently achievable way is to consider creative and cultural norms as part of the assessment of remedies in infringement cases. Courts tend to presume that infringement causes irreparable harm to a copyright owner, but equity does not require them to make that presumption. ${ }^{106}$ Injunctions are a discretionary remedy. ${ }^{107}$ In situations where the defendant's use does not clearly threaten an established licensing market and is non-substitutive, why not treat infringement under a liability rule? Australian courts could take guidance from the US Supreme Court in requiring a plaintiff to show that they have suffered or will suffer irreparable harm without an injunction and that monetary remedies are inadequate. ${ }^{108}$ This would have the additional advantage of discouraging more frivolous suits and encouraging action only where the plaintiff has been demonstrably harmed. ${ }^{109}$ Where the use does not result in a market substitute and does not cause direct

103 Ibid 3.

104 Law should not always follow norms, particularly where norms have been cultivated in situations involving serious power imbalances: see Jennifer E Rothman, 'In the Shadow of the Law: The Role of Custom in Intellectual Property' in Ben Depoorter and Peter Menell (eds), Research Handbook on the Economics of Intellectual Property, Volume 1: Theory (Edward Elgar, 2019) ch 20. However, we submit that the norms of creators and creative communities are a useful guide for the copyright law that purports to regulate creative practice and re-use.

105 Pappalardo et al (n 62) 31-6. See also Aufderheide et al (n 72).

106 See above nn $20-9$ and accompanying text.

107 Cardile v LED Builders Pty Ltd (1999) 198 CLR 380, 396 (Gaudron, McHugh, Gummow and Callinan JJ); Tagget v Sexton (2009) 255 ALR 522, 531 [46] (Beazley JA), quoting Cardile v LED Builders Pty Ltd (1999) 198 CLR 380, 405-6 [56]-[57] (Gaudron, McHugh, Gummow and Callinan JJ). For copyright, see Copyright Act s 115(2).

108 eBay, Inc v Mercexchange LLC, 547 US 388, 391-4 (2006).

109 Sprigman (n 38) 323-4, 340-1. 
financial harm, then the most appropriate remedy is likely to be nominal damages and no injunctive relief. Such an approach is likely to cultivate, rather than hinder, creative activity. It offers support for transformative uses such as documentary films and remixes, and it provides some important breathing space for creators to get on with the practice of creativity, rather than being stymied by protracted licensing negotiations. ${ }^{110}$

An approach to remedies that compensates only where actual harm has been suffered or is likely will enable creators and users to make determinations about their copyright practices with more confidence and care. It also more properly aligns not only with norms of creative practice, but with public perceptions about the fairness of copyright law. As one creator said to us: 'I think the punishment far outweighs the crime. It's just seen as in a really black and white perspective. That - you've broken a law, so therefore, I get to put you in court and [you give us] lots and lots of money. In terms of culture, there's nothing to be gained from that'. The complaint here is not that creators and users should be able to do whatever they want with existing content. Rather, our interviewees stressed that they are always trying to do the right thing and to treat existing works and other creators with respect. They simply want to know that if they have done the wrong thing, the legal remedy will be proportionate to the wrong.

\section{B Empowering Moral Rights}

The most common metaphor in copyright is that of property - the so-called bundle of economic rights owned and controlled by the copyright owner. ${ }^{111}$ Copyright owners are able to exclude others from copying or using their works in the same way that a property owner can exclude trespassers from their land. ${ }^{112}$ Our studies suggest that Australian creators and consumers tend not to see copyright interests in this way, however. Rather, they describe copyright as a means of managing creative conversations and relationships, and of securing certain behaviours that fit with their conceptions of respectful re-use, such as proper attribution.

Fortunately for Australian creators and consumers, the rights of attribution and integrity are enshrined in the Copyright Act as moral rights. ${ }^{113}$ Less fortunate, though, is that moral rights are generally treated as a separate regime from the more robust economic rights, and a seldom-invoked one at that. The Australian moral rights regime lacks teeth, reliable precedent, and comprehensive guidance on when the moral right of integrity, in particular, will be breached.

110 See also Joseph P Liu, 'Copyright and Breathing Space' (2007) 30 Columbia Journal of Law \& Arts 429; Wendy J Gordon, 'Harmless Use: Gleaning from the Fields of Copyrighted Works' (2009) 77(5) Fordham Law Review 2411, 2433.

111 On copyright's property metaphors, see Patricia Loughlan, 'Pirates, Parasites, Reapers, Sowers, Fruits, Foxes ... The Metaphors of Intellectual Property’ (2006) 28(2) Sydney Law Review 211; Mark Lemley, 'Property, Intellectual Property, and Free Riding' (2005) 83(4) Texas Law Review 1031.

112 See, eg, William M Landes and Richard A Posner, 'An Economic Analysis of Copyright Law' (1989) 18(2) Journal of Legal Studies 325, 344.

113 Copyright Act ss 193, 195ABA, 195AC, 195AHA, 195AI, 195ALA. 
Moral rights could be reinvigorated by drawing a stronger connection between the law and norms of practice around respectful re-use. It may even be possible for particular creator and consumer communities to work together to formalise and articulate what respectful re-use, proper attribution and reasonableness mean to them. Peter Jaszi and Patricia Aufderheide have had great success in the United States working with discrete communities to build consensus-based codes of best practice around what those communities consider to be 'fair' and 'unfair' uses under US copyright law. ${ }^{114}$ These codes have proved instrumental in helping creative communities to determine and communicate when they do and do not expect permission to be obtained in advance for certain uses and the general conditions of 'fair use' within their community, and the codes have created enough sector stability that even practices around insurance have settled. ${ }^{115}$ We could imagine that if similar work was done with Australian creators and consumers around shared understandings of 'respectful re-use', in line with the attribution and integrity requirements in our moral rights provisions, then this could have a powerful impact on both practices and copyright case law. If copyright owners were asked to show harm (in line with our suggestions above) and creators and users were expected to demonstrate respectful re-use, then not only does the uncertainty around tolerated uses start to diminish, but we also start to gather more and better information about the actual 'harms and benefits of different uses of copyrighted works', ${ }^{116}$ which can inform how we understand and apply copyright law in future cases. These norms and practices can then reliably guide creators, consumers, copyright owners and courts, as well as the intermediary platforms on which many consumers engage. Greater information can help to clarify, stabilise and legitimise our copyright law for the digital age.

Our thought experiment is this: instead of asking whether or not individuals have acquired permission in advance, what would it mean to open a conversation about copyright by considering whether people have attributed correctly and treated a work with respect? To take this seriously, courts would need to treat copyright as a liability rule and not a property rule. ${ }^{17}$ It also means that where uses are non-substitutive and the user has acted in accordance with moral rights, in most cases damages should only be nominal.

114 Patricia Aufderheide and Peter Jaszi, Reclaiming Fair Use: How to Put Balance Back in Copyright (University of Chicago Press, $2^{\text {nd }}$ ed, 2018). See the various codes of best practices at American University, 'Codes of Best Practices', Center for Media \& Social Impact (Web Page) $<$ http://cmsimpact.org/codes-of-best-practices/>. For a considered critique of this work, see Rothman (n 104).

115 Patricia Aufderheide and Aram Sinnreich, 'Documentarians, Fair Use and Free Expression: Changes in Copyright Attitudes and Actions with Access to Best Practices' (2016) 19(2) Information, Communication \& Society 178, 180-1.

116 Sprigman (n 38) 324-5, 328.

117 See Calabresi and Melamed (n 8) 1092. 


\section{CONCLUSION}

In this article, we have advanced a proposal that where copyright infringement does not cause direct economic harm to a copyright owner because the infringing use is non-substitutive, and where the existing work has been attributed and treated with integrity, the infringement should be treated as a liability rule. Courts should use their discretion in granting remedies to decline to grant an injunction (ie, decline to treat the infringement as a property rule) and, where appropriate, to grant only nominal damages. While this proposition may mark a shift in doctrine, it would mainly explicitly recognise the current dominant practical reality, where copyright owners only rarely enforce their rights against ordinary acts that are technically infringing but generally harmless. We suggest that there may be two big advantages of this shift. First, it would better align the law with social norms, an increasingly important challenge in a time when the acceptance of copyright principles is under great strain. Second, it would reduce the potential for inequity where rights-holders seek to enforce their rights not because their economic or moral interests are harmed, but because of personal, political, anti-competitive, or other reasons that are orthogonal to the protection that copyright grants 